\title{
Breast cancer in elderly patients : the sentinel node biopsy
}

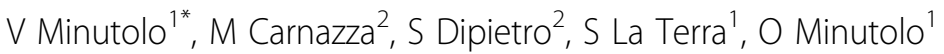 \\ From de Senectute: Age and Health Forum \\ Catanzaro, Italy. 5-7 December 2009
}

\section{Background}

The sentinel node biopsy in elderly women remains a controversial issue. Recent studies concluded that conservative breast surgery such as as the sentinel node technique can be performed in elderly patients [1-3]. The technique is safe and without additional risk compared with the young, but there is a tendency to perform no or less extensive axillary surgery $[4,5]$. Some authors argue that in elderly patients with early breast cancer and clinically negative axillary lymph nodes, axillary dissection such as the sentinel node biopsy and postoperative radiotherapy may not be necessary because of reduced life expectancy [6] and the ability to predict which elderly patients may have low probability of lymph node metastasis may be spared the morbidity of lymph node evaluation [7]. The sentinel node biopsy in elderly patients is feasible and mortality data between older and younger do not show major differences when adjusted for associated pathologies [2]. The stage of disease and comorbidities must be considered for treatment of cancer in elderly patients.

The purpose of this study is to demonstrate the feasibility and safety of sentinel node biopsy in elderly patients.

\section{Materials and methods}

40 patients with breast cancer underwent sentinel node biopsy. All patients underwent lymphoscintigraphy the day before surgery. 15 patients had passed the age of 70 and three the age of 80. Diabetes and heart disease were present in 7 patients.

\section{Results}

A total of 18 patients aged $\geq 70$ years (median 75,91 years, range 70-82) with operable breast cancer who

${ }^{1}$ Department of Surgical Sciences, Organ Transplantations and Advanced Technologies - Catania University of Studies, Italy underwent sentinel node biopsy were included in the study. The sentinel node (SN) was identified in all the patients, with an identification rate of $100 \%$. The sentinel node was localized in 37 patients (92.5\%). All patients underwent breast-conserving surgery.

The sentinel node was positive for metastasis in $3 / 18$ $(16,66 \%)$ patients who, after intraoperative diagnosis, underwent complete axillary dissection in the same surgical procedure .Definitive histological examination showed that two patients had only the sentinel node invaded..No complications we found in axillary lymph node recurrence either.

\section{Conclusion}

The results obtained are similar in patients above and below 70 years of age. The indication for surgical treatment, conservative or demolition of the breast, is independent of age of the patient. The sentinel node biopsy is feasible and safe in elderly patients with an individualized approach and can reliably predict the state of the axilla and avoids unnecessary treatment of healthy lymph nodes excision and reduces hospitalization and costs.

\section{Author details}

'Department of Surgical Sciences, Organ Transplantations and Advanced Technologies - Catania University of Studies, Italy. ${ }^{2}$ General Surgery C.O.U. Hospital " Guzzardi", Vittoria ( Rg), Italy.

Published: 19 May 2010

\footnotetext{
References

1. Paaschburg B, Pedersen A, Tuxen MK, Nielsen MM, Kroman N: Treatment of elderly patients with breast cancer. Ugeskr Laeger 2008, 170(14):1133-8.

2. Roberto Gennari, Nicole Rotmensz, Elisa Perego, Gabriela dos Santos, Umberto Veronesi: Sentinel node biopsy in elderly breast cancer patients. Surgical Oncology 2004, 13:193-196.

3. Bernardi D, Errante D, Galligioni E, Crivellari D, Bianco A, Salvagno L, Fentiman IS: Treatment of breast cancer in older women. Acta Oncol 2008, 47(2):187-198.
} 
4. Kemeny MM, Busch-Devereaux E, Merriam LT, et al: Cancer surgery in the elderly. Hematology-Oncology Clinics of North America 2000, 14:169-92.

5. Audisio RA, Bozzetti F, Gennari R, Jaklitsch MT, Koperna T, Longo WE, Wiggers T, Zbar AP: The surgical management of senior cancer patients: opinions of the SIOG surgical task force. European Journal of Cancer 2004, 40:926-38.

6. Martelli G, Miceli R, Costa A, Coradini D, Zurrida S, Piromalli D, Vetrella G Greco M: Elderly breast cancer patients treated by conservative surgery alone plus adjuvant tamoxifen: fifteen-year results of a prospective study. Cancer 2008, 112(3):481-8.

7. Chagpar $A B, M c M a s t e r s ~ K M$, Edwards MJ: North American Fareston Tamoxifen Adjuvant Trial. Can sentinel node biopsy be avoided in some elderly breast cancer patients? Ann Surg. 2009, 249(3):455-60.

doi:10.1186/1471-2318-10-S1-A13

Cite this article as: Minutolo et al:: Breast cancer in elderly patients : the sentinel node biopsy. BMC Geriatrics 2010 10(Suppl 1):A13.

\section{Submit your next manuscript to BioMed Central} and take full advantage of:

- Convenient online submission

- Thorough peer review

- No space constraints or color figure charges

- Immediate publication on acceptance

- Inclusion in PubMed, CAS, Scopus and Google Scholar

- Research which is freely available for redistribution

Submit your manuscript at www.biomedcentral.com/submit 